\title{
Mechanism of Action of Mangifera indica Leaves for Anti-Diabetic Activity
}

\author{
Dai-Hung Ngo ${ }^{1}$, Dai-Nghiep Ngo ${ }^{2}$, Thi Thanh Nhan Vo ${ }^{1}$ and Thanh Sang Vo ${ }^{3, *}$ \\ 1 Faculty of Natural Sciences, Thu Dau Mot University, Thu Dau Mot City 820000, Binh Duong province, \\ Vietnam; hungnd@tdmu.edu.vn (D.-H.N.); nhanvtt@tdmu.edu.vn (T.T.N.V.) \\ 2 Faculty of Biology and Biotechnology, University of Science, Vietnam National University, \\ Ho Chi Minh City 700000, Vietnam; ndnghiep@hcmus.edu.vn \\ 3 NTT Hi-Tech Institute, Nguyen Tat Thanh University, Ho Chi Minh City 700000, Vietnam \\ * Correspondence: vtsang@ntt.edu.vn; Tel.: +84-28-62717296
}

Received: 4 April 2019; Accepted: 28 May 2019; Published: 31 May 2019

check for updates

\begin{abstract}
Diabetes is a major metabolic disorder whose prevalence is increasing daily. Medicinal plants have played an important role in the prevention and treatment of type 2 diabetes via prophylactic and therapeutic management. In this study, Mangifera Indica leaf (MIL) extract was investigated for its promising anti-diabetic activity via an in vitro model. It was found that MIL extract possessed significant inhibition on alpha-amylase activity up to (51.4 \pm 2.7$) \%$ at a concentration of $200 \mu \mathrm{g} / \mathrm{mL}$. Moreover, glucose adsorption capacity of MIL was identified at $(2.7 \pm 0.19) \mathrm{mM}$ glucose/g extract. Furthermore, the extract caused a significant increase in glucose uptake up to $(143 \pm 9.3) \%$ in LO-2 liver cells. Notably, MIL extract was effective in scavenging $(63.3 \pm 2.1) \%$ 1,1-diphenyl-2-picryl-hydrazyl (DPPH) and (71.6 \pm 4.3$) \%$ 2,2-azinobis-3-ethyl benzothiazoline-6-sulfonic acid (ABTS) ${ }^{+}$radicals and inhibiting $(66 \pm 4.9) \%$ NO production from RAW264.7 cells without any cytotoxicity effects. Accordingly, $M$. indica leaves are suggested as a promising material for development of hypoglycemic products.
\end{abstract}

Keywords: herbal plant; alpha-amylase; anti-diabetes; NO production; glucose uptake

\section{Introduction}

Diabetes is one of the most frequent non-communicable lifestyle-related diseases in the world. According to World Health Organization projections, around 300 million will be affected by diabetes by the year 2025 [1]. In particular, diabetes mellitus is a major metabolic disorder whose prevalence is increasing daily. It is characterized by the relative or absolute deficiency of insulin secretion and/or insulin action that causes glucose intolerance and impairs lipid, carbohydrate, and protein metabolisms [2,3]. Long-term diabetic patients experience complications of retinopathy, nephropathy, and peripheral neuropathy [4]. Currently, the oral anti-diabetic drugs, such as sulfonylureas, biguanides, $\alpha$-glucosidase inhibitors, thiazolidinediones, and dipeptidyl peptidase- 4 inhibitors, are the main therapies for type-2 diabetes [5]. However, these drugs are ineffective in long-term regulation of the glycemic level and exhibit many undesirable side effects. Therefore, the discovery of safer and more effective anti-diabetic agents is still necessary.

Mangifera Indica (mango) is a large evergreen tree in the Anacardiaceae family that is the most popular of all tropical fruits from Asia. It is estimated that there are about 1000 mango varieties with various names grown all over the world. India is known to be the highest mango cultivating country [6]. M. indica has been an important herb in the Ayurvedic and indigenous medical systems for over 4000 years. Various parts of the plant, such as bark, leaves, roots, fruits, and flowers, have been applied as dentifrice, antiseptic, astringent, diaphoretic, stomachic, vermifuge, tonic, laxative, 
and diuretic agents, and have been used to treat diarrhea, dysentery, anemia, asthma, bronchitis, cough, hypertension, insomnia, rheumatism, toothache, leucorrhoea, hemorrhage, and piles [7]. Recently, a large variety of phytochemicals have been reported in M. indica. Among them, polyphenols are the most abundant compound types in M. indica, including mangiferin, gallic acid, catechins, quercetin, kaempferol, protocatechuic acid, ellagic acids, propyl and methyl gallate, rhamnetin, and anthocyanins [8]. As the result, $M$. indica exhibits various pharmacological potentials, such as anticancer, anti-inflammatory, antidiabetic, antioxidant, antibacterial, antifungal, anthelmintic, gastroprotective, hepatoprotective, antiplasmodial, antihyperlipidemic [9], and immunostimulatory activities [10], and toxicity effects at high doses (18.4 g/ $\mathrm{kg}$ in mice) [11]. Especially, in vivo studies on anti-diabetes of $M$. indica leaves have been reported [12-14]. In the present study, in vitro anti-diabetic effects of $M$. indica leaves wert investigated on alpha-amylase inhibition, glucose adsorption and glucose uptake capacity, radical scavenging activity, NO production suppression, and cell viability.

\section{Results and Discussion}

\subsection{Alpha-Amylase Inhibitory Activity}

Alpha-amylase is the most important digestive enzyme that catalyzes the hydrolysis of alpha- 1,4 glycosidic linkages of carbohydrates. It cleaves the large starch molecules into smaller fragments of sugars to cross the gut epithelium. In a healthy person, excess levels of sugar will be converted to energy sources. However, in some cases, high levels of blood glucose due to excess activity of alpha-amylase results in hyperglycemia [15]. Thus, the inhibition of alpha-amylase activity can reduce postprandial hyperglycemia and prevent the risk of diabetes development $[16,17]$. In this study, ethanol extract of M. indica leaves (MIL) was investigated for its capability against alpha-amylase activity. The results showed that MIL extract significantly inhibited alpha-amylase activity in a dose-dependent manner (Figure 1). The inhibitory effect was observed up to $(51.4 \pm 2.7) \%$ at a concentration of $200 \mu \mathrm{g} / \mathrm{mL}$. Meanwhile, acarbose exhibited an inhibitory effect of $(59 \pm 5.3) \%$ at a concentration of $100 \mu \mathrm{g} / \mathrm{mL}$. This result indicates that the inhibitory ability of MIL extract on alpha-amylase was stronger than that of Momordica charantia ( $\mathrm{IC}_{50}$ was $0.267 \pm 0.024 \mathrm{mg} / \mathrm{mL}$ ) [18] and was less effective than that of Physalis angulata fruit extract (97.2\% inhibition at $100 \mu \mathrm{g} / \mathrm{mL}$ ) [19]. Currently, acarbose, miglito, and voglibose are common anti-diabetic drugs that mainly act by inhibiting carbohydrate digestive enzymes, such as $\alpha$-amylase, sucrose, maltase, and $\alpha$-glucosidase [20]. Moreover, mice treated with acarbose slowed their breakdown of sucrose and starch [21]. Hence, the inhibitory effect of MIL extract on alpha-amylase activity may contribute to the hypoglycemia in type 2 diabetes.

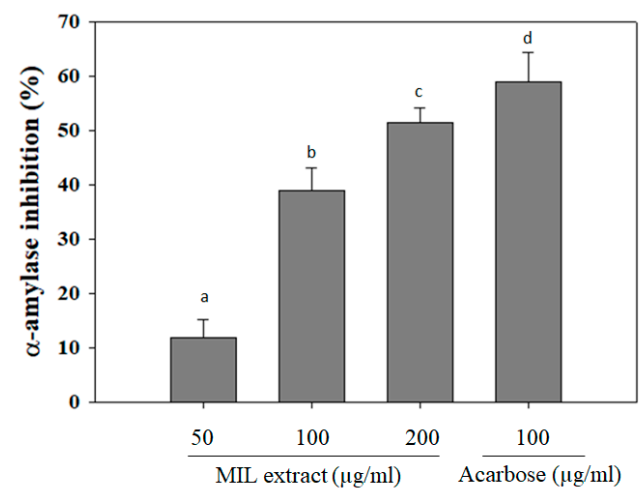

Figure 1. $\alpha$-amylase inhibitory activity of Mangifera indica leaves (MIL) extract. The extract was pre-incubated with $\alpha$-amylase for 30 min before adding starch solution. Reaction was stopped by DNS reagent and boiled for $5 \mathrm{~min}$. Absorbance was measured at $540 \mathrm{~nm}$. Acarbose was used as a positive control. Each determination was made in three independent experiments, and the data are shown as means \pm SD. Different letters a-d indicate significant difference among groups $(p<0.05)$ by Duncan's multiple-range test. 


\subsection{Glucose Adsorption Capacity}

It was reported that various hypoglycemic herbs, such as ginseng, bitter melon, fenugreek, banaba, Gymnema sylvestre, and Coptis chinensis, can reduce intestinal glucose adsorption in type 2 diabetes patients [22]. Herein, the glucose adsorption capacity of MIL extract was exhibited at the concentration of $1 \%(w / v)$ (Figure 2). The adsorption capacity of the extract was directly proportional to the glucose concentration. It was observed that the increase of the bound glucose level was accompanied with the increased glucose concentration. At glucose concentrations of 10, 50, or $100 \mathrm{mM}$, the adsorption capacity of MIL was $(0.8 \pm 0.12) \mathrm{mM} / \mathrm{g}$ extract, $(2.1 \pm 0.07) \mathrm{mM} / \mathrm{g}$ extract, and $(2.7 \pm 0.19) \mathrm{mM} / \mathrm{g}$ extract, respectively. The adsorption capacity of the extract may be attributed to their phytoconstituents, such as insoluble and soluble constituents and fibers, that have been reported to be able adsorb glucose [23]. According to Bisoi and colleagues, various insoluble fibers from locally available whole grain of millets and cereals, such as kodo millet (Paspalum scrobiculatum), proso millet (Panicum miliaceum), barnyard millet (Echinochloa frumentacea), finger millet (Eleusine coracana), wheat (Triticum aestivum), and great millet (Sorghum vulgare) exhibited their glucose adsorption capacity of up to $(0.49 \pm 0.02)-(1.07 \pm 0.02)$ $\mathrm{mM} / \mathrm{g}$ fiber at a glucose concentration of $50 \mathrm{mM}$ [24]. Obviously, the glucose adsorption capacity of these insoluble fibers was less effective than that of MIL extract. Thus, MIL extract could be suggested to decrease the transport of glucose across in the intestinal lumen and, subsequently, reduce the postprandial hyperglycemia.

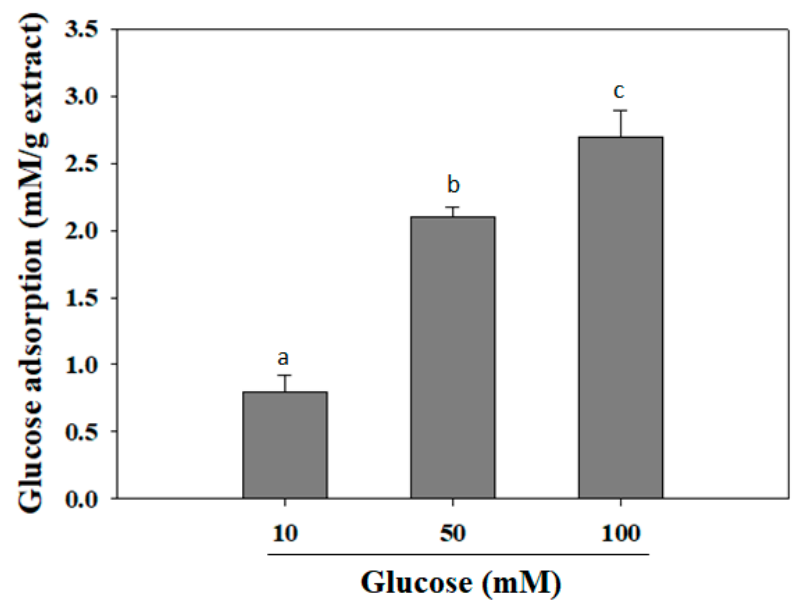

Figure 2. Glucose adsorption capacity of $M$. indica leaf extract. The extract was added to glucose solution and mixed well for $6 \mathrm{~h}$. The mixture was then centrifuged and glucose content in the supernatant was determined. Each determination was made in three independent experiments, and the data are shown as means \pm SD. Different letters a-c indicate significant difference among groups $(p<0.05)$ by Duncan's multiple-range test.

\subsection{The Effect MIL Extract on Glucose Uptake}

Individuals with normal glucose tolerance are highly sensitive to insulin in skeletal muscle, adipose tissue, and liver [25]. Whereas, the type 2 diabetic patients are insulin resistant, which associates with a decrease in glucose uptake and increase in endogenic hepatic glucose production, thus leading to a hyperglycemic situation [26]. Especially, bioactive agents, which can stimulate glucose uptake, play an important role in the reduction of hyperglycemia in type 2 diabetic patients [27]. In this study, glucose uptake capacity of MIL extract was examined by using LO-2 cells as an in vitro model (Figure 3). Interestingly, MIL extract treatment increased glucose uptake in LO-2 cells when compared to the control (without extract treatment). MIL extract exhibited glucose uptake up to $(143 \pm 9.3) \%$ at a concentration of $200 \mu \mathrm{g} / \mathrm{mL}$. However, glucose uptake capacity of MIL extract was observed to be lower than that of metformin $(197 \%$ at $20 \mu \mathrm{g} / \mathrm{mL})$ and Brachylaena elliptica $(121 \%$ at $100 \mu \mathrm{g} / \mathrm{mL}$ ) [28]. It was reported that several phytochemical compounds, such as phenols, terpenoids 
flavonoids, and flavanols, can reduce glucose release and increase glucose uptake, thus contributing to the amelioration of hyperglycemia in type 2 diabetes [29]. As a result, glucose uptake capacity of MIL extract may be suggested to improve hyperglycemia due to these phytochemical compounds. Although this action could not be attributed to the anti-hyperglycemic mechanism significantly, MIL extract could be anticipated to lower blood glucose when used as functional food for diabetic patients.

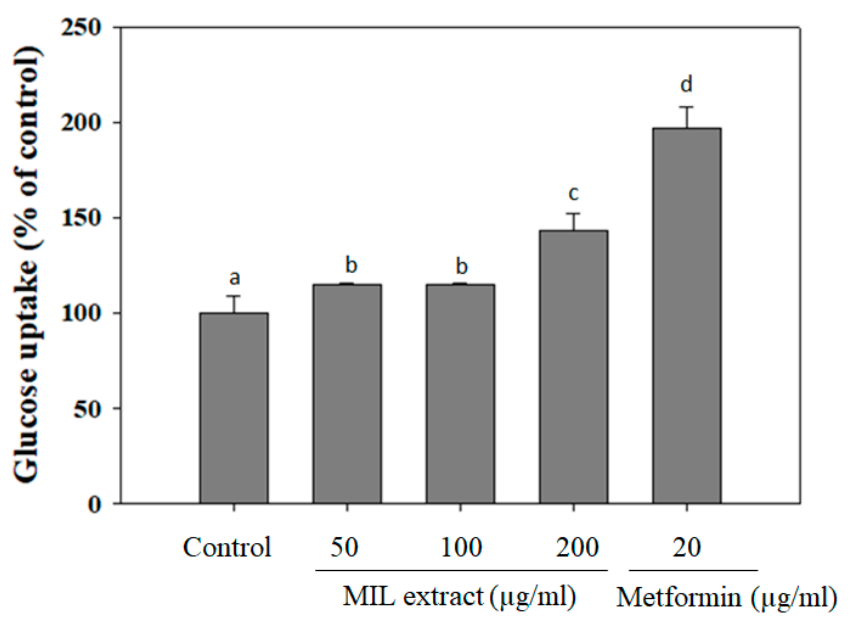

Figure 3. Glucose uptake capacity of $M$. indica leaves (MIL) extract in human hepatic LO-2 cells. LO-2 cells were incubated with the extract for $48 \mathrm{~h}$ before replacing the spent culture medium by incubation buffer (Phosphate-buffered saline (PBS), $0.1 \%$ bovine serum albumin (BSA) and $8 \mathrm{mM}$ glucose). The mixture was further incubated for $3 \mathrm{~h}$ and the glucose concentration in supernatant was then measured. Metformin was used as a positive control. The results were expressed as percentage of control. Each determination was made in three independent experiments, and the data are shown as means \pm SD. Different letters a-d indicate significant difference among groups $(p<0.05)$ by Duncan's multiple-range test.

\subsection{The Free Radical Scavenging Activities}

Free radicals are unstable and reactive chemical entities that contain one or more unpaired electrons [30]. The free radicals induce cell damage via passing unpaired electron that cause oxidation of cell components and molecules, such as lipids, proteins, and DNA [31]. Notably, free radical activity has been previously implicated in the development of diabetic vascular complications in diabetes mellitus [32]. Long-term complication of diabetes mellitus is associated with various oxidative reactions, free radical generation, and oxidative stress [33]. Therefore, antioxidants will neutralize the free radicals, protect the cells against toxic effect of radicals, and prevent pathogenesis as well as complications of diabetes mellitus [34]. Herein, the antioxidant activity of MIL extract was investigated via measuring its scavenging ability on DPPH and $\mathrm{ABTS}^{+}$radicals (Figure 4). It was showed that MIL extract significantly scavenged DPPH and $\mathrm{ABTS}^{+}$radicals up to $(63.3 \pm 2.1) \%$ and $(71.6 \pm 4.3) \%$ at a concentration of $200 \mu \mathrm{g} / \mathrm{mL}$, respectively. However, the free radical scavenging activities of MIL extract were weaker than that of positive control (Vitamin C). It was evidenced that antioxidant components of plants, such as vitamins, carotenoids, flavonoids, anthocynins, tannins, and other phenolic compounds, were able to ameliorate diabetes [35]. Thus, the high antioxidant property of MIL extract may contribute to delay the development of free radicals-related diabetes. 

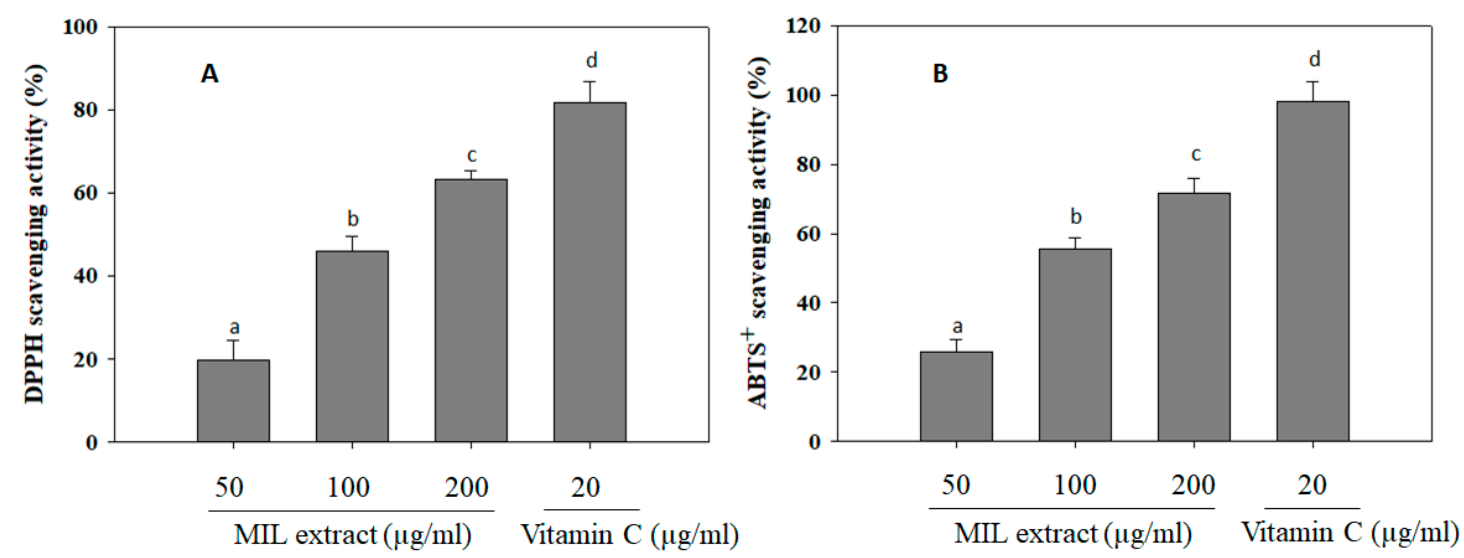

Figure 4. DPPH and $\mathrm{ABTS}^{+}$scavenging activities of $M$. indica leaves (MIL) extract. (A) The extract $(100 \mu \mathrm{L})$ was mixed with $100 \mu \mathrm{L}$ DPPH solution and subsequently incubated in the dark at room temperature for $30 \mathrm{~min}$. Absorbance of the mixture was then measured at $490 \mathrm{~nm}$. (B) The extract $(100 \mu \mathrm{L})$ was mixed with $900 \mu \mathrm{L} \mathrm{ABTS}^{+}$solution and subsequently incubated in the dark at room temperature for $15 \mathrm{~min}$. Measurement was taken at $734 \mathrm{~nm}$. Vitamin $C$ was used as a positive control. Each determination was made in three independent experiments, and the data are shown as means \pm SD. Different letters a-d indicate significant difference among groups $(p<0.05)$ by Duncan's multiple-range test.

\subsection{The Inhibitory Effect of MIL Extract on Nitric Oxide (NO) Production}

Nitric oxide (NO) is known as a key regulatory molecule with extensive metabolic, vascular, and cellular effects [36]. It is beneficial for several physiological and cellular functions at low level. However, high levels of NO may cause detrimental effects in the cells due to generating peroxynitrite radicals, subsequently binding to proteins and, thus, affecting their function [37]. Notably, it has been evidenced that diabetic rats and patients with hyperglycemia showed higher NO levels when compared to controls [38]. Thus, NO may cause the development of diabetes complications, both microvascular and cardiovascular [39]. In order to investigate NO production, the RAW 264.7 macrophage cells were pre-treated with MIL extract before stimulation of LPS. The levels of NO production were calculated as a percentage compared to that of the control (without extract treatment). In this assay, NO production levels were decreased in RAW 264.7 macrophage cells pre-treated with the extract (Figure 5). The levels of NO production were reduced to $(96 \pm 7.5) \%$, $(72 \pm 8.3) \%$, or $(48 \pm 4.9) \%$ in the presence of 50,100 , or $200 \mu \mathrm{g} / \mathrm{mL}$ of MIL extract, respectively. Meanwhile, ibuprofen reduced NO production to $(22 \pm 6.3) \%$ at a concentration of $100 \mu \mathrm{g} / \mathrm{mL}$. In other studies, NO production levels were reduced to $70 \%$ and $60 \%$ when RAW 264.7 cells were pre-treated with oolong tea $(50 \mu \mathrm{g} / \mathrm{mL})$ [40] or red ginger $(100 \mu \mathrm{g} / \mathrm{mL})$ [41], respectively. Obviously, the inhibitory activity of MIL extract on NO production was slightly weaker than that of oolong tea (Camellia sinensis) and red ginger (Zingiber officinale). Accordingly, the free radical scavenging activities and NO inhibitory effect of MIL extract may partly contribute to the prevention of complications in type 2 diabetes. 


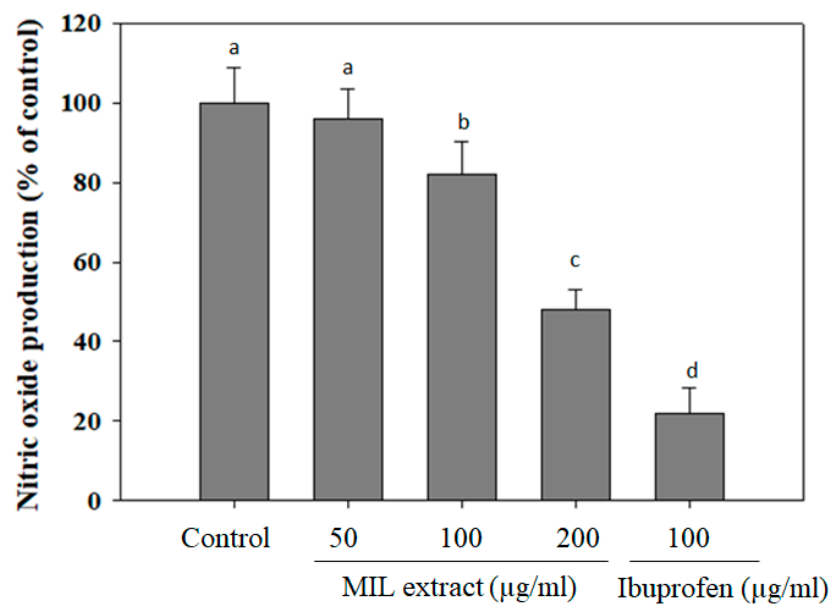

Figure 5. Inhibitory effect of $M$. indica leaves (MIL) extract on NO production from LPS-stimulated RAW 264.7 cells. The cells were treated with the extract for $12 \mathrm{~h}$ prior to stimulation of LPS for $12 \mathrm{~h}$. Aliquots $(50 \mu \mathrm{L})$ of supernatants was incubated with $50 \mu \mathrm{L}$ of Griess reagent for $15 \mathrm{~min}$. Absorbance was measured at $540 \mathrm{~nm}$. Ibuprofen was used as a positive control. The results were expressed as percentage of control. Each determination was made in three independent experiments, and the data are shown as means \pm SD. Different letters a-d indicate significant difference among groups $(p<0.05)$ by Duncan's multiple-range test.

\subsection{Effect of Extract on Cell Viability}

Medicinal plants have long been used for maintaining human health and continue to be a valuable source of pharmaceuticals up to now [42]. Besides being of great significance in therapeutic treatments, medicinal plants also exhibited cytotoxic potential due to the production of various cytotoxic substances for defense purposes [43]. Thus, an assessment of their cytotoxic potential is necessary to ensure relatively safe use of medicinal plants. The MTT colorimetric assay is a common in vitro method for cytotoxic test which was applied for investigation of cytotoxic potential of $M$. indica leaves extract in this study [44]. Obviously, the liver has many important functions, especially the metabolism of pharmaceutical agents. Thus, it is susceptible to damage by pharmaceutical agents and their metabolites [45]. Moreover, pharmaceutical agents were also reported to influence the immune system [46]. Hence, the studies of hepatotoxicity and immunotoxicity due to dosage, metabolism, stress response, and immune response are important and necessary for the screening of safe and effective pharmaceutical drugs. Herein, in vitro hepatotoxic and immunotoxic effects of $M$. indica leaves extract were examined on hepatic LO-2 cells and RAW 264.7 macrophage cells by MTT assay. The cells were pre-treated with different concentrations of the extract for $24 \mathrm{~h}$, and cell viability was measured to identify cytotoxic levels. In Figure 6, the cell viability level induced by MIL extract was shown in a range of $82-97 \%$ for LO-2 cells and 88-99\% for RAW 264.7 macrophage cells when compared with the blank (no addition of extract). These results indicate that $M$. indica leaves extract exhibited no significant cytotoxicity effect on hepatic cells and macrophage cells at a range of concentration of 50 to $200 \mu \mathrm{g} / \mathrm{mL}$. However, the further studies related to cytotoxicity effect of $M$. indica leaves extract on a clinical trial model are needed.

Obviously, polyphenols or foods rich in polyphenols have been evidenced to alleviate the hyperglycemia and increase insulin secretion and sensitivity [47]. These positive effects were reported due to a decrease in glucose absorption, inhibition of carbohydrate digestive enzymes, promotion of $\beta$-cells function, and activation of glucose uptake into the insulin-sensitive tissues [47]. Moreover, high antioxidant and anti-inflammatory activities of polyphenols have contributed to the protection against diabetes-related complications such as retinopathy, nephropathy, and neuropathy [47]. Notably, $M$. indica leaves were identified to contain various phenolic constituents, such as caffeic and gallic acids [48], mangiferin [49], flavonoids [50], and volatile compounds [51]. Especially, mangiferin, 
a bioactive compound, has been found as major constituent of $M$. indica leaves [49]. Therefore, mangiferin may be mainly responsible for the pharmaceutical properties of $M$. indica leaves, particularly anti-diabetes. Moreover, Zhang and colleagues have confirmed that short-term administration of M. indica leaves was safe at a maximum dose of $18.4 \mathrm{~g} / \mathrm{kg}$ on mice [11]. Meanwhile, the long-term administration showed slight body weight increase and higher fat weights in rats. A slight increase in serum cholesterol and triglycerides levels and epididymis weight was observed in male rats, while the weight of the liver, kidney, and adrenal gland was higher in female rats when compared to the control group. However, all animals were normal in hematology, coagulation function, biochemical criteria, gross anatomy, and relative organs weight. According to these results, the hypoglycemic effect of $M$. indica leaves in both short and long-term administration in a clinical trial should be further evaluated.
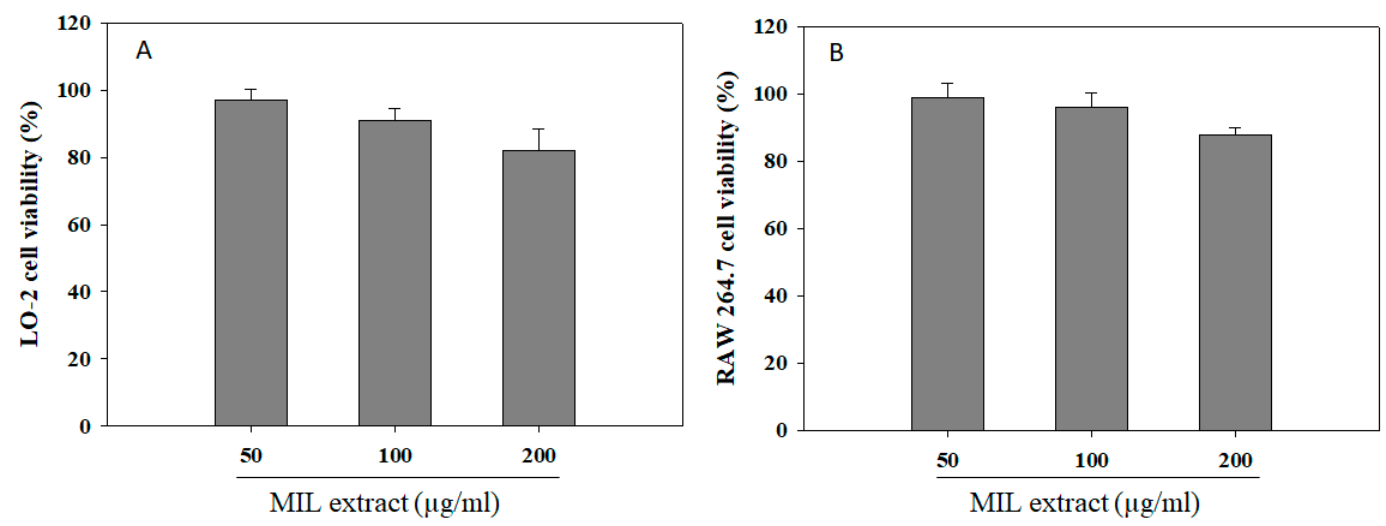

Figure 6. Cell viability of M. indica leaves (MIL) extract on hepatic LO-2 cells (A) and RAW 264.7 macrophage cells (B). The cells were incubated with the extract for $24 \mathrm{~h}$. Cell viability was assessed by MTT method, and the results were expressed as percentage of surviving cells over blank cells. Each determination was made in three independent experiments, and the data are shown as means \pm SD.

\section{Materials and Methods}

\subsection{Materials}

Leaves of Mangifera indica were collected from Tay Ninh province, Vietnam. Alpha-amylase from Bacillus licheniformis (A4582) was purchased from Sigma-Aldrich (USA). Solvent was purchased from Xilong (China). Acarbose and metformin was purchased from the pharmacy store at district 7, Ho Chi Minh city, Vietnam. All other reagents were purchased from Sigma-Aldrich (St. Louis, MO, USA).

\subsection{Extraction}

Materials were air-dried under shade and powdered by a grinder. The powder was soaked with ethanol following the extract conditions: ratio $(1 / 4, w / v)$, time $(4 \mathrm{~h})$, and temperature $\left(60^{\circ} \mathrm{C}\right)$. The ethanol extracts were kept at $4{ }^{\circ} \mathrm{C}$ for further investigation.

\subsection{Alpha-Amylase Inhibitory Assay}

The inhibition of $\alpha$-amylase activity was carried out by dinitrosalicylic acid (DNS) method [52]. Briefly, $1 \mathrm{~mL}$ of the extract $(50,100$, or $200 \mu \mathrm{g} / \mathrm{mL})$ or acarbose $(100 \mu \mathrm{g} / \mathrm{mL})$ was pre-incubated with $1 \mathrm{~mL}$ of $\alpha$-amylase (A4582, diluted for 10,000 in $20 \mathrm{mM}$ sodium phosphate buffer, $\mathrm{pH}$ 6.9) for 30 min before adding $1 \mathrm{~mL}(1 \% w / v)$ of starch solution. The mixture was further incubated at $37^{\circ} \mathrm{C}$ for $10 \mathrm{~min}$. The reaction was then stopped by adding $1 \mathrm{~mL}$ DNS reagent $(12.0 \mathrm{~g}$ of sodium potassium tartrate tetrahydrate in $8 \mathrm{~mL}$ of $2 \mathrm{M} \mathrm{NaOH}$ and $96 \mathrm{mM}$ 3,5-dinitrosalicylic acid solution), and the content was heated in a boiling water bath for $5 \mathrm{~min}$. The control (C) was prepared without the extract, 
and the blank (B) is without $\alpha$-amylase. Absorbance was measured at $540 \mathrm{~nm}$ using Genova Nano (Jenway, UK). Acarbose was used as a reference. The percentage of inhibition was calculated by the following formula:

$$
\text { Inhibition }(\%)=\left[\left(\mathrm{OD}_{\mathrm{C}}-\mathrm{OD}_{\mathrm{B}}\right)-\left(\mathrm{OD}_{\text {sample }}-\mathrm{OD}_{\mathrm{B}}\right)\right] /\left(\mathrm{OD}_{\mathrm{C}}-\mathrm{OD}_{\mathrm{B}}\right)^{*} 100 \%
$$

\subsection{Determination of Glucose Adsorption Capacity}

The glucose adsorption capacity of the extract was determined according to Ou et al. [53]. The extract $(1 \%, w / v)$ was added to $25 \mathrm{~mL}$ of glucose solution $(10,50$, or $100 \mathrm{mM})$ and incubated in a shaker water bath at $37^{\circ} \mathrm{C}$ for $6 \mathrm{~h}$. The mixture was centrifuged at $4000 \mathrm{~g}$ for $20 \mathrm{~min}$, and glucose content in the supernatant was determined. Glucose adsorption was calculated by using the following formula (G1 is the glucose concentration of the original solution; G2 is the glucose concentration after $6 \mathrm{~h}$ ):

$$
\text { Glucose adsorption }=\left[(\mathrm{G} 1-\mathrm{G} 2)^{*} \text { Volume of solution }\right] / \text { Weight of sample }
$$

\subsection{Glucose Uptake in Hepatic LO-2 Cells}

Human hepatic LO-2 cells were cultured in a humidified atmosphere containing $5 \% \mathrm{CO}_{2}$ at $37{ }^{\circ} \mathrm{C}$ using Dulbecco's modified eagle medium (DMEM) supplemented with $5 \%$ heat-inactivated fetal bovine serum (FBS), $10 \mathrm{mM}$ HEPES buffer, $100 \mathrm{U} / \mathrm{mL}$ of penicillin G, and $100 \mathrm{mg} / \mathrm{mL}$ of streptomycin. Glucose uptake was determined as described by van de Venter et al. [54]. Briefly, the cells $\left(1 \times 10^{4} \mathrm{cells} / \mathrm{mL}\right)$ were incubated with either the extract $(50,100$, or $200 \mu \mathrm{g} / \mathrm{mL})$ or metformin $(20 \mu \mathrm{g} / \mathrm{mL})$ for $48 \mathrm{~h}$. The spent culture medium was then removed and replaced with $50 \mu \mathrm{L}$ incubation buffer (PBS, $0.1 \%$ BSA and $8 \mathrm{mM}$ glucose) before being incubated for $3 \mathrm{~h}$ at $37^{\circ} \mathrm{C}$. Glucose concentration in the supernatant was measured by using Contour Plus Meter (Ascensia Diabetes Care, Switzerland). The percentage of glucose uptake was calculated as a percentage compared to the control $C$ (the untreated cell group). Glucose uptake amount was calculated according to the following formula ( $\mathrm{T}$ is glucose concentration in supernatant of the treated cell group, while $C$ is glucose concentration in supernatant of the untreated cell group):

$$
\text { Glucose uptake }(\%)=[(8-\mathrm{T}) /(8-\mathrm{C})]^{*} 100
$$

\subsection{1,1-Diphenyl-2-Picryl-Hydrazyl Assay}

Antioxidant activity of the extract was determined by the 1,1-diphenyl-2-picryl-hydrazyl (DPPH) assay, as described by Vo et al. [55]. Briefly, $100 \mu \mathrm{L}$ of the extract (50, 100, or $200 \mu \mathrm{g} / \mathrm{mL})$ or vitamin $\mathrm{C}(20 \mu \mathrm{g} / \mathrm{mL})$ was mixed with $100 \mu \mathrm{L}$ of DPPH solution before being incubated in the dark at room temperature for $30 \mathrm{~min}$. Absorbance of the mixture was then measured at $490 \mathrm{~nm}$ by using Genova Nano (Jenway, UK). Vitamin C was used as a reference. DPPH scavenging ability was determined as following formula:

$$
\text { DPPH scavenging effect }(\%)=\left[\left(\mathrm{OD}_{\text {control }}-\mathrm{OD}_{\text {sample }}\right) / \mathrm{OD}_{\text {control }}\right] \times 100 \%
$$

\subsection{2,2-Azinobis-3-Ethyl Benzothiazoline-6-Sulfonic Acid (ABTS) Assay}

This assay was performed as described by Vo et al. [55]. Photometric assay was conducted on $0.9 \mathrm{~mL}$ of $\mathrm{ABTS}^{+}$solution and $0.1 \mathrm{~mL}$ of the extract $(50,100$, or $200 \mu \mathrm{g} / \mathrm{mL})$ or vitamin $\mathrm{C}(20 \mu \mathrm{g} / \mathrm{mL})$. The mixture was mixed for $45 \mathrm{sec}$ and incubated for $15 \mathrm{~min}$ before measured at $734 \mathrm{~nm}$ by using Genova Nano (Jenway, UK). Vitamin C was used as a reference. ABTS $^{+}$scavenging ability was determined as following formula:

$$
\mathrm{ABTS}^{+} \text {scavenging effect }(\%)=\left[\left(\mathrm{OD}_{\text {control }}-\mathrm{OD}_{\text {sample }}\right) / \mathrm{OD}_{\text {control }}\right] \times 100 \%
$$




\subsection{Nitric Oxide Production Assay}

Nitric oxide (NO) level in the culture supernatant was measured by the Griess reaction, as described by Vo et al. [56]. Briefly, RAW 264.7 macrophage cells were plated at $1 \times 10^{5}$ cells $/ \mathrm{mL}$ in 96-well culture plates, and treated with different concentration of the extract $(50,100$, or $200 \mu \mathrm{g} / \mathrm{mL})$ or ibuprofen $(100 \mu \mathrm{g} / \mathrm{mL})$ for $12 \mathrm{~h}$ prior to stimulation of LPS $(1 \mu \mathrm{g} / \mathrm{mL}$, final concentration) for $12 \mathrm{~h}$. Aliquots $(50 \mu \mathrm{L})$ of supernatant were incubated with $50 \mu \mathrm{L}$ of Griess reagent for $15 \mathrm{~min}$. This was followed by measurement of absorbance values at $540 \mathrm{~nm}$ using microplate reader (Tecan Austria $\mathrm{GmbH}$, Grodig/Salzburg, Austria). The nitrite oxide level was calculated as a percentage compared to control: release ratio $(\%)=(T-B) /(C-B) \times 100$, where $B$ is the group without stimulation as well as sample treatment, $\mathrm{C}$ is the stimulated group without treatment of the tested sample, and $\mathrm{T}$ is the stimulated group with presence of the tested sample.

\subsection{Cell Viability Assay}

Cell viability level was determined by MTT assay. In brief, the cells $\left(1 \times 10^{5}\right.$ cells $\left./ \mathrm{mL}\right)$ were incubated with the extract $(50,100$, or $200 \mu \mathrm{g} / \mathrm{mL})$ for $24 \mathrm{~h}$. Medium was removed, and the cells were incubated with a solution of $1 \mathrm{mg} / \mathrm{mL}$ MTT for $4 \mathrm{~h}$. Finally, supernatant was removed, and DMSO was added to solubilize formazan salt. Formazan salt amount was determined by measuring absorbance at $540 \mathrm{~nm}$ using a microplate reader (Tecan Austria GmbH, Grodig/Salzburg, Austria). The cell viability was calculated as a percentage compared to blank.

\subsection{Statistical Analysis}

Data were analyzed using the analysis of variance (ANOVA) test of statistical package for the social sciences (SPSS). The statistical differences among groups were assessed by using Duncan's multiple range tests. Differences were considered significant at $p<0.05$.

\section{Conclusions}

Herbal plants are a huge source of potential bioactive components for therapy and management of diabetes. Herein, M. indica leaf extract has been evidenced as a promising anti-diabetic agent by inhibiting starch digestive enzyme, possessing glucose adsorption and glucose uptake capacity, suppressing NO production, and scavenging free radicals. Although the activities of commercial drugs were observed to be stronger than $M$. indica leaf extract, the potential hypoglycemic and antioxidant activities of $M$. indica leaves extract, evidenced in the present study, could be beneficial for type 2 diabetic patients. Hence, the present study provided useful evidence for the development of a functional hypoglycemic product from $M$. indica leaves. However, further studies related to the safety and efficacy need to be evaluated for long-term use of M. indica leaves.

Author Contributions: Conceptualization, D.-H.N.; Methodology, D.-N.N.; Validation, D.-H.N. and T.S.V.; Formal Analysis, T.T.N.V.; Investigation, T.T.N.V., D.-H.N., and T.S.V.; Data Curation, D.-N.N.; Writing-Review \& Editing, T.S.V.; Visualization, D.-H.N.

Acknowledgments: This research was supported by TDMU Foundation for Science and Technology Development, Thu Dau Mot University, Thu Dau Mot city, Binh Duong province, Vietnam.

Conflicts of Interest: The authors declare no conflict of interest.

\section{References}

1. Hung, H.Y.; Qian, K.; Morris-Natschke, S.L.; Hsu, C.S.; Lee, K.H. Recent discovery of plant-derived anti-diabetic natural products. Nat. Prod. Rep. 2012, 29, 580-606. [CrossRef] [PubMed]

2. Guillausseau, P.J.; Meas, T.; Virally, M.; Laloi-Michelin, M.; Médeau, V.; Kevorkian, J.P. Abnormalities in insulin secretion in type 2 diabetes mellitus. Diabetes Metab. 2008, 34, S43-S48. [CrossRef]

3. Medina Escobar, P.; Moser, M.; Risch, L.; Risch, M.; Nydegger, U.E.; Stanga, Z. Impaired glucose metabolism and type 2 diabetes in apparently healthy senior citizens. Swiss Med. Wkly. 2015, 145, w14209. 
4. White, N.H. Long-term outcomes in youth with diabetes mellitus. Pediatr. Clin. N. Am. 2015, 62, 889-909. [CrossRef]

5. Chaudhury, A.; Duvoor, C.; Reddy Dendi, V.S.; Kraleti, S.; Chada, A.; Ravilla, R.; Marco, A.; Shekhawat, N.S.; Montales, M.T.; Kuriakose, K.; et al. Clinical review of antidiabetic drugs: Implications for type 2 diabetes mellitus management. Front. Endocrinol. 2017, 8, 6. [CrossRef] [PubMed]

6. Ediriweera, M.K.; Tennekoon, K.H.; Samarakoon, S.R. A Review on ethnopharmacological applications, pharmacological activities, and bioactive compounds of Mangifera indica (Mango). Evid. Based Complement. Altern. Med. 2017, 2017, 6949835. [CrossRef] [PubMed]

7. Shah, K.A.; Patel, M.B.; Patel, R.J.; Parmar, P.K. Mangifera Indica (Mango). Pharmacogn. Rev. 2010, 4, 42-48. [CrossRef]

8. Barreto, J.C.; Trevisan, M.T.S.; Hull, W.E.; Erben, G.; de Brito, E.S.; Pfundstein, B.; Würtele, G.; Spiegelhalder, B.; Owen, R.W. Characterization and quantitation of polyphenolic compounds in bark, kernel, leaves, and peel of mango (Mangifera indica L.). J. Agric. Food Chem. 2008, 56, 5599-5610. [CrossRef]

9. Lauricella, M.; Emanuele, S.; Calvaruso, G.; Giuliano, M.; D’Anneo, A. Multifaceted health benefits of Mangifera indica L. (Mango): The inestimable value of orchards recently planted in sicilian rural areas. Nutrients 2017, 9, 525. [CrossRef] [PubMed]

10. Kumolosasi, E.; Ibrahim, S.A.; Shukri, S.A.; Ahmad, W. Immunostimulant activity of standardised extracts of Mangifera indica leaf and Curcuma domestica rhizome in mice. Trop. J. Pharm. Res. 2018, 17, 77-84. [CrossRef]

11. Zhang, Y.; Li, J.; Wu, Z.; Liu, E.; Shi, P.; Han, L.; Guo, L.; Gao, X.; Wang, T. Acute and long-term toxicity of mango leaves extract in mice and rats. Evid. Based Complement. Altern. Med. 2014, 2014, 691574. [CrossRef] [PubMed]

12. Sharma, S.R.; Dwivedi, S.K.; Swarup, D. Hypoglycaemic potential of Mangifera indica leaves in rats. Int. J. Pharm. 1997, 35, 130-133. [CrossRef]

13. Aderibigbe, A.O.; Emudianughe, T.S.; Lawal, B.A. Antihyperglycaemic effect of Mangifera indica in rat. Phytother. Res. 1999, 13, 504-507. [CrossRef]

14. Wadood, N.; Wadood, A.; Shah, S.A. Effect of Mangifera indica on blood glucose and total lipid levels of normal and alloxan diabetic rabbits. Planta Med. 1992, 58, 131-136. [CrossRef] [PubMed]

15. Mahmood, N. A review of $\alpha$-amylase inhibitors on weight loss and glycemic control in pathological state such as obesity and diabetes. Comp. Clin. Path. 2016, 25, 1253-1264. [CrossRef]

16. Rehman, K.; Chohan, T.A.; Waheed, I.; Gilani, Z.; Akash, M.S.H. Taxifolin prevents postprandial hyperglycemia by regulating the activity of $\alpha$-amylase: Evidence from an in vivo and in silico studies. J. Cell Biochem. 2019, 120, 425-438. [CrossRef]

17. Kato, E.; Kushibiki, N.; Inagaki, Y.; Kurokawa, M.; Kawabata, J. Astilbe thunbergii reduces postprandial hyperglycemia in a type 2 diabetes rat model via pancreatic alpha-amylase inhibition by highly condensed procyanidins. Biosci. Biotechnol. Biochem. 2017, 81, 1699-1705. [CrossRef]

18. Poovitha, S.; Parani, M. In vitro and in vivo $\alpha$-amylase and $\alpha$-glucosidase inhibiting activities of the protein extracts from two varieties of bitter gourd (Momordica charantia L.). BMC Complement. Altern. Med. 2016, 16, 185. [CrossRef]

19. Poojari, S.; Porika, R.; Mamidala, E. Phytochemical analysis and in vitro antidiabetic activities of Physalis Angulata fruit extracts. Natl. J. Integr. Res. Med. 2014, 5, 34-38.

20. Agarwal, P.; Gupta, R. Alpha-amylase inhibition can treat diabetes mellitus. J. Med. Health Sci. 2016, 5, 1-8.

21. Fang, W.; Wei, C.; Dong, Y.; Tang, X.; Zu, Y.; Chen, Q. The effect on gut microbiota structure of primarily diagnosed type 2 diabetes patients intervened by sancai lianmei particle and acarbose: A randomized controlled trial. J. Clin. Trials 2016, 6, 270. [CrossRef]

22. Prabhakar, P.K.; Doble, M. Mechanism of action of natural products used in the treatment of diabetes mellitus. Chin. J. Integr. Med. 2011, 17, 563-574. [CrossRef]

23. Perry, J.R.; Ying, W. A review of physiological effects of soluble and insoluble dietary fibers. J. Nutr. Food Sci. 2016, 6, 476.

24. Bisoi, P.C.; Sahoo, G.; Mishra, S.K.; Das, C.; Das, K.L. Hypoglycemic Effects of Insoluble Fiber Rich Fraction of Different Cereals and Millets. J. Food Process. Technol. 2012, 3, 191.

25. Tripathy, D.; Carlsson, M.; Almgren, P.; Isomaa, B.; Taskinen, M.R.; Tuomi, T.; Groop, L.C. Insulin secretion and insulin sensitivity in relation to glucose tolerance: Lessons from the Botnia Study. Diabetes 2000, 49, 975-980. [CrossRef] 
26. Schinner, S.; Scherbaum, W.A.; Bornstein, S.R.; Barthel, A. Molecular mechanisms of insulin resistance. Diabet. Med. 2005, 22, 674-682. [CrossRef]

27. Xia, E.Q.; Zhu, S.S.; He, M.J.; Luo, F.; Fu, C.; Zou, T.B. Marine peptides as potential agents for the management of type 2 diabetes mellitus-A prospect. Mar. Drugs 2017, 15, 88. [CrossRef]

28. Sagbo, I.J.; van de Venter, M.; Koekemoer, T.; Bradley, G. In vitro antidiabetic activity and mechanism of action of Brachylaena elliptica (Thunb.) DC. J. Evid. Based Complement. Altern. Med. 2018, 2018, 4170372. [CrossRef]

29. Hanhineva, K.; Törrönen, R.; Bondia-Pons, I.; Pekkinen, J.; Kolehmainen, M.; Mykkänen, H.; Poutanen, K. Impact of dietary polyphenols on carbohydrate metabolism. Int. J. Mol. Sci. 2010, 11, 1365-1402. [CrossRef]

30. Rao, P.S.; Kalva, S.; Yerramilli, A.; Mamidi, S. Free radicals and tissue damage: Role of antioxidants. Free Rad. Antiox. 2011, 1, 2-7.

31. Asmat, U.; Abad, K.; Ismail, K. Diabetes mellitus and oxidative stress-A concise review. Saudi Pharm. J. 2016, 24, 547-553. [CrossRef]

32. Chikezie, P.C.; Ojiako, O.A.; Ogbuji, A.C. Oxidative stress in diabetes mellitus. Int. J. Biol. Chem. 2015, 9, 92-109. [CrossRef]

33. Singh, R.; Devi, S.; Gollen, R. Role of free radical in atherosclerosis, diabetes and dyslipidaemia: Larger-than-life. Diabetes Metab. Res. Rev. 2015, 31, 113-126. [CrossRef]

34. Zatalia, S.R.; Sanusi, H. The role of antioxidants in the pathophysiology, complications, and management of diabetes mellitus. Acta Med. Indones 2013, 45, 141-147.

35. Aryaeian, N.; Sedehi, S.K.; Arablou, T. Polyphenols and their effects on diabetes management: A review. Med. J. Islam Repub. Iran. 2017, 31, 134. [CrossRef] [PubMed]

36. Tessari, P.; Cecchet, D.; Cosma, A.; Vettore, M.; Coracina, A.; Millioni, R.; Iori, E.; Puricelli, L.; Avogaro, A.; Vedovato, M. Nitric oxide synthesis is reduced in subjects with type 2 diabetes and nephropathy. Diabetes 2010, 59, 2152-2159. [CrossRef]

37. Pal, P.; Joseph, S.B.; Lucas, L. Nitric oxide and peroxynitrite in health and disease. Physiol. Rev. 2007, 87, 315-424.

38. Adela, R.; Nethi, S.K.; Bagul, P.K.; Barui, A.K.; Mattapally, S.; Kuncha, M.; Patra, C.R.; Reddy, P.N.; Banerjee, S.K. Hyperglycaemia enhances nitric oxide production in diabetes: A study from south indian patients. PLoS ONE 2015, 10, e0125270. [CrossRef] [PubMed]

39. Giacco, F.; Brownlee, M. Oxidative stress and diabetic complications. Circ. Res. 2010, 107, 1058-1070. [CrossRef]

40. Novilla, A.; Djamhuri, D.S.; Nurhayati, B.; Rihibiha, D.D.; Afifah, E.; Widowati, W. Anti-inflammatory properties of oolong tea (Camellia sinensis) ethanol extract and epigallocatechin gallate in LPS-induced RAW 264.7 cells. Asian Pac. J. Trop. Biomed. 2017, 7, 1005-1009. [CrossRef]

41. Shimoda, H.; Shan, S.J.; Tanaka, J.; Seki, A.; Seo, J.W.; Kasajima, N.; Tamura, S.; Ke, Y.; Murakami, N. Anti-inflammatory properties of red ginger (Zingiber officinale var. Rubra) extract and suppression of nitric oxide production by its constituents. J. Med. Food 2010, 13, 156-162. [CrossRef]

42. Sen, T.; Samanta, S.K. Medicinal plants, human health and biodiversity: A broad review. Adv. Biochem. Eng. Biotechnol. 2015, 147, 59-110. [PubMed]

43. Mazid, M.; Khan, T.A.; Mohammad, F. Role of secondary metabolites in defense mechanisms of plants. Biol. Med. 2011, 3, 232-249.

44. Edmondson, J.M.; Armstrang, L.S.; Martiner, A.O. A rapid and simple MTT-basedspectrophotometric assay for determining drug sensitivity in monolayercultures. J. Tissue Cult. Methods 1998, 11, 15-17. [CrossRef]

45. Bale, S.S.; Vernetti, L.; Senutovitch, N.; Jindal, R.; Hegde, M.; Gough, A.; McCarty, W.J.; Bakan, A.; Bhushan, A.; Shun, T.Y.; et al. In vitro platforms for evaluating liver toxicity. Exp. Biol. Med. 2014, 239, 1180-1191. [CrossRef] [PubMed]

46. Descotes, J. Immunotoxicity of pharmaceuticals: An introduction. Drug Inf. J. 1996, 30, 271-274. [CrossRef]

47. Bahadoran, Z.; Mirmiran, P.; Azizi, F. Dietary polyphenols as potential nutraceuticals in management of diabetes: A review. J. Diabetes Metab. Disord. 2013, 12, 43. [CrossRef]

48. Singh, U.P.; Singh, D.P.; Singh, M.; Maurya, S.; Srivastava, J.S.; Singh, R.B.; Singh, S.P. Characterization of phenolic compounds in some Indian mango cultivars. Int. J. Food Sci. Nutr. 2004, 55, 163-169. [CrossRef] [PubMed] 
49. Salomon, S.; Sevilla, I.; Betancourt, R.; Romero, A.; Nuevas-Paz, L.; Acosta-Esquijarosa, J. Extraction of mangiferin from Mangifera indica L. leaves using microwaveassisted technique. Emir. J. Food Agric. 2014, 26, 616-622. [CrossRef]

50. Kanwal, Q.; Hussain, I.; Latif Siddiqui, H.; Javaid, A. Antifungal activity of flavonoids isolated from mango (Mangifera indica L.) leaves. Nat. Prod. Res. 2010, 24, 1907-1914. [CrossRef]

51. Gebara, S.S.; de Oliveira Ferreira, W.; Ré-Poppi, N.; Simionatto, E.; Carasek, E. Volatile compounds of leaves and fruits of Mangifera indica var. coquinho (Anacardiaceae) obtained using solid phase microextraction and hydrodistillation. Food Chem. 2011, 127, 689-693. [CrossRef]

52. Bhutkar, M.A.; Bhise, S.B. In vitro assay of alpha amylase inhibitory activity of some indigenous plants. Int. J. Chem. Sci. 2012, 10, 457-462.

53. Ou, S.; Kwok, K.C.; Li, Y.; Fu, L. In vitro study of possible role of dietary fiber in lowering postprandial serum glucose. J. Agric. Food Chem. 2001, 49, 1026-1029. [CrossRef]

54. Van de Venter, M.; Roux, S.; Bungu, L.C.; Louw, J.; Crouch, N.R.; Grace, O.M.; Maharaj, V.; Pillay, P.; Sewnarian, P.; Bhagwandin, N.; et al. Antidiabetic screening and scoring of 11 plants traditionally used in South Africa. J. Ethnopharmacol. 2008, 119, 81-86. [CrossRef]

55. Vo, T.S.; Le, P.U.; Ngo, D.H. The increased gamma-aminobutyric acid content by optimizing fermentation conditions of bacteria from kimchi and investigation of its biological activities. EurAsian J. BioSci. 2018, 12, 369-376.

56. Vo, T.S.; Le, P.U.; Ngo, D.H. Free radical scavenging and anti-proliferative activities of avocado (Persea americana Mill.) seed extract. Asian Pac. J. Trop. Biomed. 2019, 9, 91-97.

(C) 2019 by the authors. Licensee MDPI, Basel, Switzerland. This article is an open access article distributed under the terms and conditions of the Creative Commons Attribution (CC BY) license (http://creativecommons.org/licenses/by/4.0/). 